\title{
Root anatomy and apical canal morphology of maxillary first premolars
}

\author{
Marina Kacarska ${ }^{1} *$, Julija Zivadinovic ${ }^{2}$ \\ ${ }^{\text {I}}$ Faculty of Dentistry, Ss. Cyril and Methodius University, Mother Theresa 43, \\ 1000 Skopje, Republic of Macedonia \\ ${ }^{2}$ Institute of anatomy, Faculty of Medicine, Ss. Cyril and Methodius University, \\ 50 Division 6,1000 Skopje, Republic of Macedonia
}

Received: July 2018; Accepted: August 2018

\begin{abstract}
Understanding the root anatomy and apical canal morphology of maxillary premolars is a key prerequisite for successful surgical and endodontic treatment. The aim of this study was to assess the root anatomy and apical canal morphology of maxillary first premolars.

To achieve the set task, 30 maxillary first premolars were extracted. After thorough rinse visual assessment of root anatomy was made. Each root was transversally sectioned six millimeters from apex with a straight hand piece. The apical samples were decalcificated in $7.5 \%$ trichloroacetic acid, transversal sections were made, stored in $10 \%$ formalin then dyed in hematoxylin and eosin and numerated from I to VI. Apical canal morphology was evaluated with an optical microscope.

Majority of maxillary first premolars had double roots $(63.0 \% ; n=19)$ that were mostly separated $(50.0 \%$; $n=15)$ containing a single root canal. Minority had double roots that were fused $(13.0 \% ; n=4)$ with two root canals. Single root with almost equal occurrence of two, as well as variable root canal configuration were found in $(30.0 \%$; $=9)$. A very rare occurrence of maxillary first premolars with three roots $(7.0 \% ; n=2)$ was detected, two vestibular and one palatal, each containing a single canal configuration. Accessory lateral canals were detected in $20 \%$ of maxillary first premolars. Transversal communications were detected in maxillary premolars with one root and double fused roots $(26.6 \% ; \mathrm{n}=8)$. A single apical foramen was detected in majority of maxillary first premolars $(50.0 \%$; $=15)$. Two apical foramina were detected in $(33.4 \% ; n=10)$, three in $(10.0 \% ; n=3)$ and four in $(6.6 \% ; n=2)$ maxillary premolars.
\end{abstract}

Keywords: maxillary first premolar, root anatomy, apical canal morphology, decalcification, optical microscopy

\section{Introduction}

A thorough knowledge and understanding of root anatomy and canal morphology is a key prerequisite for successful surgical and endodontic treatment.

Apical surgery of maxillary premolar is a delicate surgical procedure that incorporates removal of apical pathology, identification of number of roots and their location, root resection, examination and identification of the complex apical canal anatomy and placement of hermetic apical seal.

Intraoral and extra oral radiography is an important preoperative diagnostic tool that proffers a twodimensional image of a three-dimensional entity. Therefore, the number of roots, their shape, position and complex inner canal morphology remain questionable, even guessable.

Clinical examination and exploration, adjacent to radiographic evaluation, using various probes and canal files enables the surgeon additional information concerning the root canal morphology.

\footnotetext{
*marina_kacarska@yahoo.com
} 
Nevertheless, the apical canal morphology remains uncertain and dubious.

Hence, surgeons and endodontists are forced ad nauseam to follow their own tactile sensitivity rather than trail required preoperative anatomical landmarks with clear accuracy.

It is of paramount importance to be able to identify and verify existing root and apical canal morphology preceding surgical and endodontic procedure.

There are several published data on the root and canal morphology of maxillary first premolars. The maxillary first premolars are among the most difficult teeth to treat due to their variation in number of roots, canal configuration, the direction and longitudinal depressions of the roots, and various pulp cavity configurations (Özcan et al., 2012; Pecora et al., 1991). The relative simplicity and uniformity of the external surfaces of roots often masks internal complexity (Lee et al., 2009). The root of this tooth is very problematic, especially in the apical third. Thus, the treatment of the canal in apical portion has to be performed with great caution (Stošićet al., 2016).

The aim of the present study was to assess the root anatomy and apical canal morphology of maxillary firs premolars.

\section{Material and methods}

To achieve the set task, 30 maxillary first premolars were extracted. After thorough rinse visual assessment of root anatomy was made. Each root was transversally sectioned six millimeters from apex with a straight hand piece. The apical samples were decalcificated in $7.5 \%$ trichloroacetic acid (Merck, UK), exposed in a series of transversal sections starting and numerated from I to VI. The transversal apical sections were stored in $10 \%$ formalin and dyed in hematoxylin and eosin $\{\mathrm{H} \& \mathrm{E}\}$.

Apical canal morphology was evaluated with a Leica DM 2500 optical microscope (Leica Microsystems, Germany).

\section{Results}

Majority of first premolars had double roots (63.0\%; $\mathrm{n}=19)$ mostly separated $(50.0 \% ; \mathrm{n}=15)$, while lesser were fused $(13.0 \% ; n=4)$. The rest of the premolars had single $\operatorname{root}(30.0 \% ; \mathrm{n}=9)$ and three roots $(7.0 \% ; \mathrm{n}=2)$.

The distribution of apical canal morphology is presented on Table 1.

Maxillary first premolars with double separated roots $(50.0 \% ; \mathrm{n}=15)$ had a single apical canal configuration per root (Fig. 1a). A very rare three rooted type of premolars $(7.0 \% ; \mathrm{n}=2)$ had the same single apical canal configuration per root as well.

The maxillary first premolars with a single root $(30.0 \% ; \mathrm{n}=9)$ and double fused roots $(13.0 \% ; \mathrm{n}=4)$ demonstrated occurrence of two canal as well as variable canal configuration (Fig. 1b).

Lateral canals were detected in $20.0 \%$ of maxillary first premolars (Fig. 2).

Transversal communications were detected in maxillary premolars with one root and double fused roots $(26.6 \% ; n=8)$.

A single apical foramen was detected in the majority of maxillary first premolars $(50.0 \% ; \mathrm{n}=15)$. Two apical foramina were detected in $(33.4 \%, \mathrm{n}=10)$ of maxillary premolars (Fig. 3), three in $(10.0 \% ; n=3)$ and four foramina in $(6.6 \% ; n=2)$ maxillary premolars.

\section{Discussion}

The prime scope of this study was to assess the root and apical canal morphology of maxillary first premolars.

Single roots, two roots, and three roots have been identified in maxillary first premolars, with the number of canals ranging from one to three per root (Pineda and Kuttler, 1972).

In the present study a clear distinction between root forms was established according to recommendations of

Table 1. Distribution of apical canal morphology

\begin{tabular}{|c|c|c|c|c|c|c|}
\hline $\begin{array}{l}\text { Apical canal } \\
\text { morphology }\end{array}$ & Single root & \multicolumn{2}{|c|}{$\begin{array}{c}\text { Double roots } \\
\text { vestibular palatal }\end{array}$} & $\begin{array}{l}\text { Double roots } \\
\text { fused }\end{array}$ & \multicolumn{2}{|c|}{$\begin{array}{c}\text { Three roots } \\
\text { vestibular palatal }\end{array}$} \\
\hline one canal & 1 & 14 & 14 & 0 & 1 & 1 \\
\hline two canals & 4 & 0 & 0 & 3 & 0 & 0 \\
\hline variable canals & 4 & 1 & 1 & 1 & 0 & 0 \\
\hline Total & 9 & & & 4 & & \\
\hline
\end{tabular}



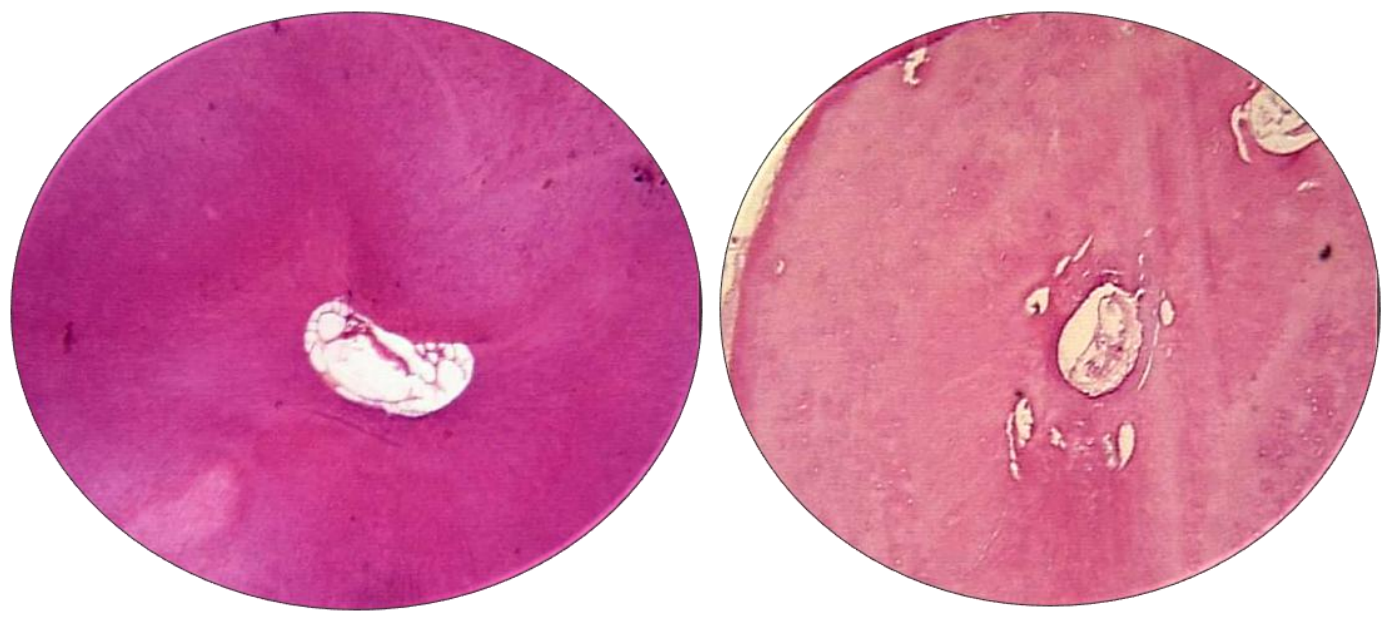

Fig. 1. Apical sample with a). one canal, b). two canals (optical microscopy, x40 magnification).

(Loh, 1998) as single, double separated roots, double fused roots and three roots. The results from our study confirmed a clear predominance of double rooted maxillary first premolars as demonstrated by other studies performed on non-Asian population (Chaparro and Segura, 1999; Pecora et al., 1991; Rwenyonyiet al., 2011; Vertucci and Gegauff, 1979; Woelfel, 2012). However, there are studies in which the upper first premolar usually had one root (Gupta et al., 2015).

Likewise, separate studies done in South-Chinese populations (Walker, 1987; Loh, 1998) have found that $60 \%$ and $50 \%$ of their samples had single root, respectively. On the other hand, almost equal distribution of single and double rooted upper first premolars with $50.6 \%$ and $49.4 \%$ respectively were reported (Carns and Scidmore, 1973; Vertucciet al., 1974). Similar findings were later observed (Loh, 1998).

Triple rooted maxillary first premolars are a very rare entity. Although the sample size of our study was modest, we encountered three rooted samples results with incidence $(7.0 \%)$ as high as the reported $0.8-6 \%$ (Atieh, 2008; Chaparro and Segura, 1999; Loh, 1998; Pecora et al., 1991; Woelfel, 2012).

The differences between the results of these morphology studies may be related to variations of examination methods, classification systems, sample sizes, and ethnic background of tooth sources (Sbernaet al., 2009).

Morphological canal variations are numerous and are particularly present in the apical root portion. Unfortunately, the results are difficult to compare, but it's obvious that root canal morphology varies greatly among different populations and even in different individuals within the same population (Vertucci, 1984).

Because of these differences in the morphology of teeth in patients of different geographic and ethnic groups (on different continents), taking precautions is necessary when relying on the results obtained from studies done in other populations (Loh, 1998).

Numerous studies were carried out, using different methods such as radiography (Willershausen et al., 2006), cleaning and decalcification (Vertucci, 2005), cutting and microscopic observation (Lu et al., 2006), and computed tomography for better understanding of the morphology of the canals (Reuben et al., 2008).

It has been reported in the literature that ex vivo demineralization and staining provides the most detailed information, while maintaining the original form and relations of canals (Gupta et al., 2015).

In our study, by implementing the method of decalcification, cutting, staining and microscopic observation, we were able to detect the variation of the apical root canal morphology of the first premolars.

Internal root canal system morphology reflects the external root anatomy. Furthermore, there is correlation between the shape of the outer surface of the root and the shape of the root canal.

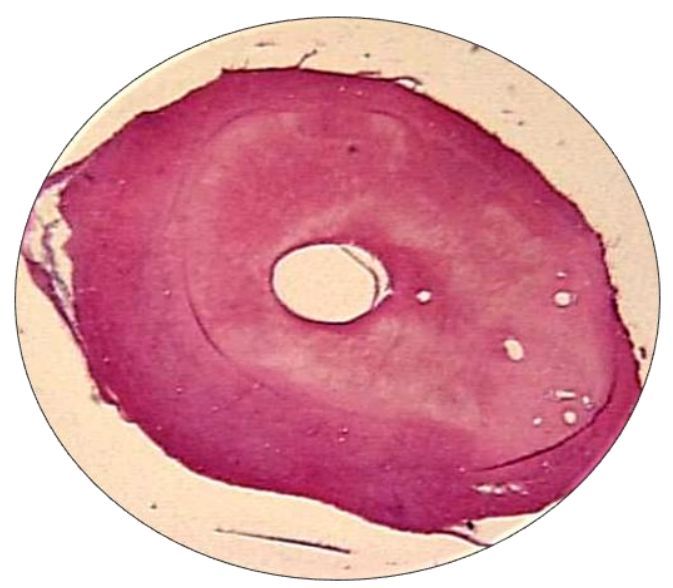

Fig. 2. Apical sample with 4 lateral canals (optical microscopy, x40 magnification). 


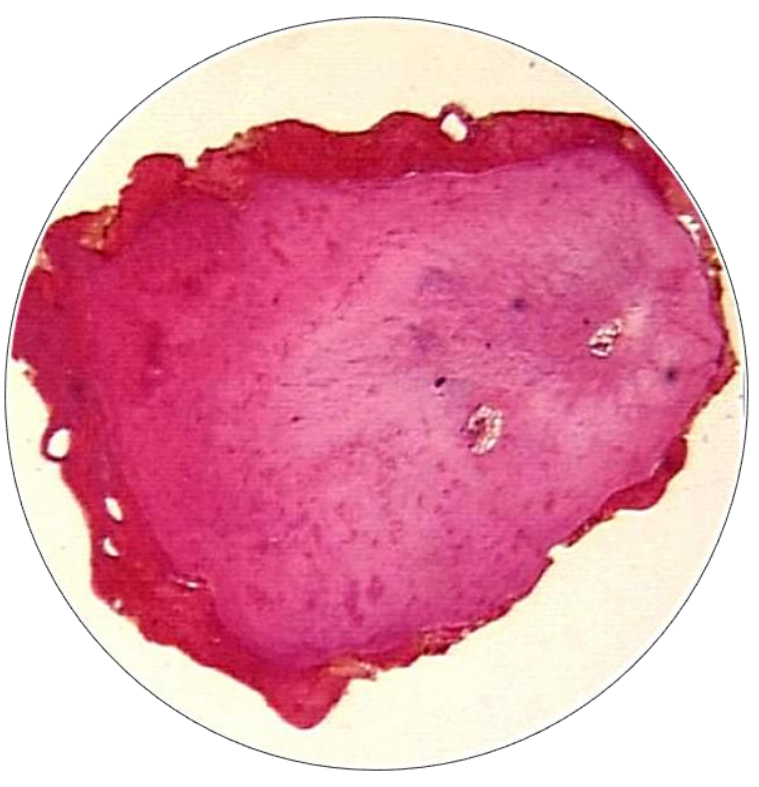

Fig. 3. Apical sample with two apical foramina (optical microscopy, x40 magnification).

Because of unpredictable variations of the apical canal system of maxillary first premolars, the canal assessment of successive apical transversal sections was performed with stereo microscope and magnification.

Our results of predominant single apical canal configuration in maxillary double rooted and three rooted first premolars $(57.0 \%)$ were in accordance with the published study (Bulutet al., 2015).

Double rooted fused and single rooted samples expressed unpredictable apical canal morphology due to two canal structure as well as a variable one-two-one canal structures.

When two or more canals are present within a single root chances for transversal communications rise. Literature has reported a high percentage of inter canal communications in teeth with two canals. This communication is of clinical significance as it may be difficult to debride and fill it adequately (Weine, 1984).

The results from our study reported low incidence of transversal communications in maxillary premolars with two canals $(26.6 \% ; \mathrm{n}=8)$.

Lower incidence of inter-canal communication or transverse an astomoses/isthmus in $16 \%$ of the samples, with maximum being in the middle third $(8.8 \%)$ was reported (Gupta et al., 2015).

This was in accordance with the textbook of endodontics, where maximum incidence of intercanal communication was in the middle third of the root (Hargreaves and Cohen, 2011).

Accessory root canals are predominantly seen in the apical root portion (17\%) (Deus, 1995). Root-canal configurations of the maxillary first premolars were categorized at the apex level (Vertucci and Gegauff, 1979). Of the canals studied, $49.5 \%$ had lateral canals located mainly in the apical region.

The occurrence of lateral canals in our study was consistent with the reported incidence of $20.0 \%$ (Deus, 1995). The number and location of apical foramen is of clinical significance during working length determination, which often depends on the average position of the apical constriction relative to the root apex (Weine, 1984). The majority of maxillary first premolars in our study had a single apical foramen $(50.0 \% ; \mathrm{n}=15)$. However, the occurrence of two, three and four foramina with eccentric locations was also detected, although in lower number.

\section{Conclusion}

Maxillary first premolars were predominantly double rooted with presence of single apical canal morphology and a single apical foramen. But lesser presence of double and absence of triple canal morphology do not diminish the possibility of encountering such in the clinical praxis.

\section{References}

Bulut, D.G., Kose, E., Ozcan, G., Sekerci, A.E., Canger, E.M., Sisman,Y., 2015. Evaluation of root morphology and root canal configuration of premolars in the Turkish individuals using cone beam computed tomography. European Journal of Dentistry 9(4), 551-557. Available at: https://doi.org/10.4103/1305-7456.172624.

Carns, E.J., Scidmore, A.E., 1973. Configurations and deviations of root canals of maxillary premolars. Oral Surg. 36, 880-886. Available at: https://doi.org/10.1016/0030-4220(73)90340-X.

Chaparro, A.J., Segura, J.J., Guerrero, E., Jimenez-Rubio, A., Murillo, C., 1999. Number of roots and canals in maxillary first premolars: study of an Andalusian population. Endod. Dent. Traumatol. 15, 65-67. Available at: https://doi.org/10.1111/j.1600-9657.1999.tb00755.x.

De Deus, Q.D., 1975. Frequency, location and direction of the lateral secondary and accessory canals. J. Endodont. 1, 361-366. Available at: https://doi.org/10.1016/s00992399(75)80211-1.

Green, D., Brooklyn N.Y., 1973. Double canals in single roots. Oral Surg. 35(5), 689-696. Available at: https://doi.org/10.1016/0030-4220(73)90037-6.

Gupta, S., Sinha, D., Gowhar, O., Tyagi, S., Singh, N., Gupta, S., 2015. Root and canal morphology of maxillary first premolar teeth in north Indian population using clearing technique: An in vitro study. J. Conserv. Dent. 18, 232236. Available at: https://doi.org/10.4103/09720707.157260.

Hargreaves, K.M., Cohen, S., 2011. Pathways of the pulp. Chapter 7. Tooth morphology and access cavity preparation, 10th ed. Louis Missouri: Mosby Elsevier St.

Lee, Y.Y., Yen, P.Y., Pai, S.F., Yang, S.F., 2009. Maxillary first molar with six canals. J. Dent. Sci.4, 198-200. Available at: https://doi.org/10.1016/S0099-2399(88)80180-8. 
Loh, H.S., 1998. Root morphology of the maxillary first premolar in Singaporeans. Australian Dental Journal 43(6), 399-402. Available at: https://doi.org/10.1111/j.18347819.1998.tb00199.x.

Lu, T.Y., Yang S. F., Pai, S.F., 2006. Complicated root canal morphology of mandibular first premolar in a Chinese population using the cross-section method. J. Endod. 32, 932-936. Available at: https://doi.org/10.1016/j.joen.2006.04.008.

Özcan, Ç., Hamidi, 2012. Root and canal morphology of maxillary first premolars in a Turkish population. Journal of Dental Sciences 7(4), 390-394. Available at: https://doi.org/10.1016/j.jds.2012.09.003.

Pecora, J., Saquy, P.C., Sousa -Neto, N.D., Woelfel, J.B., 1991. Root form and canal anatomy of maxillary first premolars. Braz. Dent. J. 2, 87-94.

Pineda, F., Kuttler, Y., 1972. Mesiodistal and buccolingual roentogenic investigations of 7, 275 root canals. Oral Surg. 3, 101-110.

Reuben, J., Velmurugan, N., Kandaswamy, D., 2008. The evaluation of root canal morphology of the mandibular first molar in an Indian population using spiral computed tomography scan: An in vitro study. J. Endod. 34, 212-215. Available at: https://doi.org/10.1016/j.joen.2007.11.018.

Rwenyonyi, C., Kutesa, A., Muwazi, L., Buwembo, W., 2011. Root and canal morphology of maxillary first premolar teeth in a Ugandan population. Open Journal of Stomatology 1, 7-11. Available at: https://doi.org/10.4236/ojst.2011.11002.

Sberna, M.T., Rizzo, G., Zachhi, E., Capparè, P., Rubinacci, A., 2009. A preliminary study of the use of peripheral quantitative computed tomography for investigating of the root canal anatomy. Int. Endod. J. 42, 66-75. Available at: https://doi.org/10.1111/j.13652591.2008.01452.x.
Stošić, N., Dačić, S., Ranđelović, M., Jovančić, A., Đorđević, I., Cvetković, M., Ilić, D., Petrović, A., Simonović, D., 2016. Morphometric analysis of the upper premolars. Acta Facultatis Medicae Naissensis 33(1), 23-29. Available at: https://doi.org/10.1515/afmnai-2016-0003.

Vertucci, F.J., Seeling, A., Gillis,1974. Root canal morphology of the human maxillary second premolar. Oral. Surg. 58, 456. Available at: https://doi.org/10.4103/09720707.71648 .

Vertucci, F.J., Gegauff, A., 1979. Root canal morphology of the maxillary first premolar. J. Am. Dent. Assoc. 99, 194-198. Available at: https://doi.org/10.14219/jada.archive.1979.0255.

Vertucci, F.J., 1984. Root canal anatomy of the human permanent teeth. Oral Surg. Oral Med. Oral Pathol. 58, 589-599. Available at: https://doi.org/10.1016/00304220(84)90085-9.

Vertucci, F.J., 2005. Root canal morphology and its relationship to endodontic procedures. Endod. Top. 10, 3-29. Available at: https://doi.org/10.1111/j.1601-1546.2005.00129.x.

Walker, R.T., 1987. Root form and canal anatomy of maxillary first premolars in a southern Chinese population. Endod. Dent. Traumatol. 3, 130-134. Available at: https://doi.org/10.1111/j.1600-9657.1987.tb00614.x.

Weine, F.S., 1984. The enigma of the lateral canal. DCNA 28, 833-852.

Willershausen, B., Tekyatan, H., Kasaj, A., Marroquin, B.B., 2006. Roentgenographic in vitro investigation of frequency and location of curvatures in human maxillary premolars. J. Endod. 32, 307-311. Available at: https://doi.org/10.1016/j.joen.2005.09.011.

Woelfel, J., 2012. Dental anatomy, 8th ed. Wolters Kluwer, Philadelphia.

\title{
Коренска анатомија и апикална канална морфологија на максиларни први премолари
}

\author{
Марина Кацарска ${ }^{1 *}$, Јулија Живадиновиќ ${ }^{2}$ \\ ${ }^{1}$ Стоматолошки факултет, Универзитет „Св. Кирил и Методиј”, \\ Ул. Мајка Тереза 43, 1000 Скопје, Република Македонија \\ ${ }^{2}$ Институт за анатомија, Медииински факултет, \\ Универзитет „Св. Кирил и Методиј”, Ул.50 Дивизија 6, 1000 Скопје, \\ Република Македонија
}

\begin{abstract}
Клучни зборови: максиларен прв премолар, коренска анатомија, апикална канална морфологија, декалцификација, оптички микроскоп
\end{abstract}

Коренската анатомија и апикална канална морфологија на максиларните премолари е важен предуслов за успешна хируршка и ендодонтска терапија. Оваа студија има за цел да ја процени коренската анатомија и апикалната морфологија на максиларните први премолари. 
За остварување на поставената цел 30 максиларни први премолари беа екстрахирани. По темелна промивка се направи визуелна проценка на коренската анатомија. Понатаму, секој корен со насадник беше трансверзално пресечен 6 мм од коренскиот апекс. Добиените апикални примероци беа декалцинирани во 7,5\% трихлороцетна киселина, потоа трансверзално пресечени во повеќе сегменти, кои беа фиксирани во 10\% формалин и обоени со хематоксилин и еозин.

Апикалната канална морфологија беше проследена со оптички микроскоп. Најмногу премолари имаа два корена $(63,0 \% ; n=19)$ кои во најголем дел беа сепарирани $(50,0 \% ; n=15)$ секој со по еден коренски канал. Помал број беа со фузионирани два корени $(13,0 \%$; $n=4)$ и два канали. Еднокоренска анатомија со скоро еднаква застапеност на дво канална и варијабилна канална конфигурација имаа (30,0\%; n=9). Во оваастудија беше забележена и многу ретка појава на максиларни први премолари со три корени (7,0\%; n=2), два вестибуларни и еден палатинален, секој со едно канална конфигурација. Акцесорни канали беа детектирани кај 20,0\% од примероците. Трансверзални комуникации беа детектирани кај премоларите со еден корен и фузионирани корени $(26,6 \% ; n=8)$. Коренските канали завршуваа во еден апикален отворво (50,0\%; n=15) од примероците. Два апикални форамени беа детектирани во $33,4 \%(n=10)$, три во $10,0 \%(n=3)$ и четири во $6,6 \%(n=2)$ од максиларните први премолари. 